\title{
A novel locus involved in extracellular polysaccharide production and virulence of Xanthomonas campestris pathovar campestris
}

\section{Correspondence \\ Ji-Liang Tang \\ jltang@gxu.edu.cn}

Received 17 August 2006

Revised 7 November 2006

Accepted 9 November 2006

\author{
Guang-Tao Lu, Zeng-Feng Ma, Jiang-Ru Hu, Dong-Jie Tang, \\ Yong-Oiang He, Jia-Xun Feng and Ji-Liang Tang
}

Guangxi Key Laboratory of Subtropical Bioresources Conservation and Utilization, The Key Laboratory of Ministry of Education for Microbial and Plant Genetic Engineering, and College of Life Science and Technology, Guangxi University, 100 Daxue Road, Nanning, Guangxi 530004, China
Xanthomonas campestris pathovar campestris $\left(X_{c c}\right)$ is the causal agent of black rot disease in cruciferous plants. The extracellular polysaccharide (EPS) produced by $X_{c c}$ is an important pathogenicity factor and also has a range of industrial uses. In preliminary work a number of transposon-mediated insertion mutants in Xcc with defects in EPS production were identified. Here, one of these mutated loci was investigated in detail. Six ORFs within the locus (ORFs XC3811-3816) were disrupted by plasmid integration. Mutation of XC3813, XC3814 or XC3815 resulted in significantly reduced EPS production and significantly reduced virulence on the host plant Chinese radish (Raphanus sativus). The EPS production and virulence of $X C 3813, X C 3814$ and $X C 3815$ mutants could be restored by intact $X C 3813, X C 3814$ and $X C 3815$ genes, respectively, when provided in trans. Although bioinformatic analysis suggested a role for XC3814 and XC3815 in lipopolysaccharide biosynthesis, the lipopolysaccharides produced by the mutants were indistinguishable from those of the wild-type, as judged by electrophoretic mobility in SDS-polyacrylamide gels. These results reveal that $X C 3813, X C 3814$ and $X C 3815$ comprise a novel gene cluster involved in EPS production and virulence of Xcc.

\section{INTRODUCTION}

The Gram-negative bacterium Xanthomonas campestris pathovar campestris (hereafter $X c c$ ) is the causal agent of black rot disease of cruciferous crops worldwide (Onsando, 1992). The pathogen produces extracellular polysaccharide (EPS), also called xanthan gum, and a series of extracellular enzymes including amylase, endoglucanase, polygalacturonate lyase and protease that collectively contribute to pathogenesis (Dow \& Daniels, 1994). EPS plays an important role during bacterial infection. It can enhance the susceptibility of host plants by suppressing defence responses such as callus formation (Yun et al., 2006). EPS may also mask the bacterium to prevent host recognition and to enable colonization of host tissues (Alvarez, 2000). In addition to a role in bacterial virulence, xanthan has a wide variety of applications in agriculture, petroleum production and the food industry as a stabilizing, viscosifying, emulsifying, thickening and suspending agent (Kennedy \& Bradshaw, 1984).

Abbreviations: EPS, extracellular polysaccharide; FT-IR, Fourier transform infrared.
The commercial value and role in pathogenesis of xanthan has prompted a number of studies on the genetics and biochemistry of biosynthesis of this EPS in recent decades. Two loci within the Xcc genome, the gum cluster and a $35.3 \mathrm{~kb}$ gene cluster, have been demonstrated to be involved in the biosynthesis of EPS (Capage et al., 1987; Hotte et al., 1990; Vanderslice et al., 1990). The gum cluster, which is composed of 12 genes (gumB to gumM), is responsible for the sequential assembly and polymerization of pentasaccharide repeating units, and also the release of polymers into the growth medium (Ielpi et al., 1993). Certain genes such as $x a n A$ and $x a n B$, which are located within the $35.3 \mathrm{~kb}$ gene cluster, are responsible for the biosynthesis of the sugar nucleotide precursors, and are involved in both EPS and lipopolysaccharide (LPS) biosynthesis (Köplin et al., 1992). In addition, the products of $r p f, c l p$ and $p i g B$ were found to be implicated in either the positive or negative regulation of EPS production (Tang et al., 1990, 1991; De Crècy-Lagard et al., 1990; Poplawsky \& Chun, 1998).

The recent rapid development of genomics has brought about a paradigm shift in gene function research. The genomes of two Xcc strains, ATCC 33913 (da Silva et al., 2002) and 8004 (Qian et al., 2005), have recently been 
sequenced and provide a profile of genetic information with which to explore the biological characteristics of Xcc. The functions of about one-third of the ORFs are, however, yet to be assigned, and a large repertoire of genes has not been experimentally defined. One aim of the work in our laboratory is to identify further genes that influence EPS biosynthesis in Xcc. In preliminary work we isolated a number of transposon insertion mutants in Xcc strain 8004 with defects in EPS synthesis. Here we investigate one of these mutated loci in more detail.

\section{METHODS}

Bacterial strains, plasmids and growth conditions. The bacterial strains and plasmids used in this study are listed in Table 1. Escherichia coli strains were grown in LB medium (Miller, 1972) at $37^{\circ} \mathrm{C}$. Xcc strains were grown in NYG medium (per litre: $5 \mathrm{~g}$ peptone, 3 g yeast extract and $20 \mathrm{~g}$ glycerol; Daniels et al., 1984b) or the minimal medium MMX (per litre: $2.0 \mathrm{~g}\left(\mathrm{NH}_{4}\right)_{2} \mathrm{SO}_{4}, 4.0 \mathrm{~g} \mathrm{~K}_{2} \mathrm{HPO}_{4}$, $6.0 \mathrm{~g} \mathrm{KH}_{2} \mathrm{PO}_{4}, 0.2 \mathrm{~g} \mathrm{MgSO}_{4} .7 \mathrm{H}_{2} \mathrm{O}, 1.0 \mathrm{~g}$ citric acid, $5.0 \mathrm{~g}$ glucose; Daniels et al., 1984a) at $28{ }^{\circ} \mathrm{C}$. Antibiotics were added at the following concentrations as required: kanamycin (Kan) $25 \mu \mathrm{g} \mathrm{ml}^{-1}$; rifampicin (Rif) $50 \mu \mathrm{g} \mathrm{ml}^{-1}$; gentamicin $(\mathrm{Gm}) 5 \mu \mathrm{g} \mathrm{ml}^{-1}$; spectinomycin (Spc) $50 \mu \mathrm{g} \mathrm{ml}^{-1}$; and tetracycline (Tet) $5 \mu \mathrm{g} \mathrm{ml}^{-1}$ for $X c c$ and $15 \mu \mathrm{g} \mathrm{ml}^{-1}$ for E. coli.

DNA manipulations. The methods described by Sambrook et al. (1989) were used for preparation of plasmid and chromosomal DNAs, restriction digestion, DNA ligation, agarose gel electrophoresis and DNA transformation of E. coli. Conjugation between $X c c$ and E. coli strains was performed as described by Turner et al. (1984). The restriction endonucleases, T4 DNA ligase and Pfu polymerase were provided by Promega (Shanghai).

Construction of insertional mutants. Mutants of ORFs XC3811, XC3812, XC3813, XC3814, XC3815 and XC3816 were constructed using the suicide plasmid pK18mob (Schafer et al., 1994; Windgassen et al., 2000). A 300-500 bp internal fragment of the target ORF was amplified by PCR using Xcc chromosomal DNA as the template and

Table 1. Bacterial strains and plasmids

\begin{tabular}{|c|c|c|}
\hline Strain or plasmid & Relevant characteristics & Reference or source \\
\hline \multicolumn{3}{|l|}{ E. coli } \\
\hline JM109 & $\begin{array}{l}\text { recA1 endA1 gyrA96 thi supE44 relA1 } \\
\Delta(\text { lac-proAB }) / \mathrm{F}^{\prime}\left[\text { traD36 }_{\text {lacI }}{ }^{\mathrm{q}} \text { lacZ } \Delta \mathrm{M} 15\right]\end{array}$ & Yanisch-Perron et al. (1985) \\
\hline $\mathrm{DH} 5 \alpha$ & $\phi 80 \Delta l a c Z M 15$ recA1 endA1 deoR & Gibco-BRL, Life Technologies \\
\hline HB101 & recA13 rps & Boyer \& Roulland-Dussoix (1969) \\
\hline \multicolumn{3}{|l|}{$X c c$} \\
\hline 8004 & Wild-type, Rif ${ }^{r}$ & Daniels et al. (1984b) \\
\hline 151D09 & As 8004, but XC3814::Tn5gusA5, EPS-deficient, $\operatorname{Rif}^{\mathrm{r}} \operatorname{Kan}^{\mathrm{r}} \operatorname{Spc}^{\mathrm{r}} \mathrm{Gm}^{\mathrm{r}}$ & Authors' lab collection \\
\hline $3811 \mathrm{nk}$ & As 8004 , but $X C 3811:: \mathrm{pK} 18 m o b$, $\operatorname{Rif}^{\mathrm{r}} \operatorname{Kan}^{\mathrm{r}}$ & This work \\
\hline $3812 \mathrm{nk}$ & As 8004 , but $X C 3812:: \mathrm{pK} 18 m o b$, $\operatorname{Rif}^{\mathrm{r}} \operatorname{Kan}^{\mathrm{r}}$ & This work \\
\hline $3813 \mathrm{nk}$ & As 8004 , but $X C 3813:: \mathrm{pK} 18 m o b$, $\operatorname{Rif}^{\mathrm{r}} \operatorname{Kan}^{\mathrm{r}}$ & This work \\
\hline $3814 \mathrm{nk}$ & As 8004 , but $X C 3814:: p K 18 \mathrm{mob}$, Rif $^{r} \mathrm{Kan}^{r}$ & This work \\
\hline $3815 \mathrm{nk}$ & As 8004 , but $X C 3815:: \mathrm{pK} 18 m o b$, Rif $^{\mathrm{r}} \operatorname{Kan}^{\mathrm{r}}$ & This work \\
\hline 3816nk & As 8004 , but $X C 3816:: \mathrm{pK} 18 m o b, \mathrm{Rif}^{\mathrm{r}} \mathrm{Kan}^{\mathrm{r}}$ & This work \\
\hline C3813nk & 3813nk harbouring pLATC3813, $\operatorname{Rif}^{\mathrm{r}} \operatorname{Kan}^{\mathrm{r}} \operatorname{Tet}^{\mathrm{r}}$ & This work \\
\hline C3814nk & 3814nk harbouring pLATC3814, $\operatorname{Rif}^{\mathrm{r}} \operatorname{Kan}^{\mathrm{r}} \operatorname{Tet}^{\mathrm{r}}$ & This work \\
\hline C3815nk & 3815nk harbouring pLATC3815, $\operatorname{Rif}^{\mathrm{r}} \operatorname{Kan}^{\mathrm{r}} \mathrm{Tet}^{\mathrm{r}}$ & This work \\
\hline 8004/pL6gumGUS & 8004 harbouring pL6gumGUS, $\operatorname{Rif}^{r} \operatorname{Kan}^{r}$ & This work \\
\hline 3813nk/pL6gumGUS & 3813nk harbouring pL6gumGUS, $\operatorname{Rif}^{\mathrm{r}} \operatorname{Kan}^{\mathrm{r}} \mathrm{Tet}^{\mathrm{r}}$ & This work \\
\hline 3814nk/pL6gumGUS & 3814nk harbouring pL6gumGUS, $\operatorname{Rif}^{\mathrm{r}} \operatorname{Kan}^{\mathrm{r}} \mathrm{Tet}^{\mathrm{r}}$ & This work \\
\hline 3815nk/pL6gumGUS & 3815nk harbouring pL6gumGUS, $\operatorname{Rif}^{\mathrm{r}} \operatorname{Kan}^{\mathrm{r}} \mathrm{Tet}^{\mathrm{r}}$ & This work \\
\hline \multicolumn{3}{|l|}{ Plasmids } \\
\hline pLAFR3 & Broad host range cloning vector, Tet $^{\mathrm{r}}$ & Staskawicz et al. (1987) \\
\hline pLAFR6 & A promoterless derivative of pLAFR3, Tet ${ }^{r}$ & Huynh et al. (1989) \\
\hline pRK2073 & Helper plasmid, $\mathrm{Tra}^{+}, \mathrm{Mob}^{+}, \mathrm{ColE} 1, \mathrm{Spc}^{\mathrm{r}}$ & Leong et al. (1982) \\
\hline pK18mob & pUC18 derivative, $l a c Z \alpha \operatorname{Kan}^{\mathrm{r}}$, mob site; suicide plasmid in $X c c$ & Schafer et al. (1994) \\
\hline pK3813 & pK18mob containing a 459 bp internal fragment of XC3813, $\mathrm{Kan}^{\mathrm{r}}$ & This work \\
\hline pK3814 & pK18mob containing a 390 bp internal fragment of XC3814, $\mathrm{Kan}^{\mathrm{r}}$ & This work \\
\hline pK3815 & pK18mob containing a 357 bp internal fragment of XC3815, $\operatorname{Kan}^{\mathrm{r}}$ & This work \\
\hline pLATC3813 & pLAFR3 containing a $1301 \mathrm{bp}$ fragment including the XC3813 gene, $\operatorname{Tet}^{\mathrm{r}}$ & This work \\
\hline pLATC3814 & pLAFR3 containing a 1096 bp fragment including the XC3814 gene, $\operatorname{Tet}^{\mathrm{r}}$ & This work \\
\hline pLATC3815 & pLAFR3 containing a $1478 \mathrm{bp}$ fragment including the XC3815 gene, $\operatorname{Tet}^{\mathrm{r}}$ & This work \\
\hline pL6gumGUS & $\begin{array}{l}\text { pLAFR6 containing the promoter region of the gum operon fused to the } \\
\text { coding region for gusA }\end{array}$ & Vojnov et al. (2001) \\
\hline
\end{tabular}


the corresponding oligonucleotides as primers (Table 2). Primers were designed based on the ORF sequences in the genome of $X c c$ strain 8004 (accession number NC_007086). After being confirmed by sequencing, the amplified DNA fragments were cloned into pK18mob to create the recombinant plasmids. Primers were modified to give BamHI- or HindIII-compatible ends to ensure that the internal fragment was cloned in the same orientation as the lac $Z$ promoter in pK18mob. The recombinant plasmid was introduced from E. coli JM109 (Yanisch-Perron et al., 1985) into Xcc strain 8004 by triparental conjugation using pRK2073 (Leong et al., 1982) as the helper plasmid. Mutants were selected on NYG agar plates containing rifampicin and kanamycin. Transconjugants with a mutation in the target ORF were confirmed by PCR. Confirmation PCR was performed using the total DNA of the transconjugants as the template, oligonucleotide P18conF, which is located in $\mathrm{pK} 18 \mathrm{mob}$, and the corresponding oligonucleotide, which is located downstream of the target ORF, as primers. The total DNA of Xcc strain 8004 was used as the negative control. The expected PCR products were further confirmed by sequencing analysis.

Complementation of the insertional mutants. For mutant complementation, a $1301 \mathrm{bp}$ DNA fragment containing the XC3813 coding region and extending from $226 \mathrm{bp}$ upstream of the $5^{\prime}$ end to $16 \mathrm{bp}$ downstream of the $3^{\prime}$ end of the ORF, a 1096 bp DNA fragment harbouring the XC3814 coding region and extending from $259 \mathrm{bp}$ upstream of the $5^{\prime}$ end to $12 \mathrm{bp}$ downstream of the $3^{\prime}$ end of the ORF, and a 1478 bp DNA fragment including the XC3815 coding region and extending from $111 \mathrm{bp}$ upstream of the $5^{\prime}$ end to $77 \mathrm{bp}$ downstream of the $3^{\prime}$ end of the ORF were amplified using the primers $\mathrm{C} 3813 \mathrm{~F} / \mathrm{R}, \mathrm{C} 3814 \mathrm{~F} / \mathrm{R}$ and $\mathrm{C} 3815 \mathrm{~F} / \mathrm{R}$ (Table 2), respectively, and the amplified DNA fragments were cloned into plasmid pLAFR3 (Staskawicz et al., 1987) or pLAFR6 (Huynh et al., 1989) to generate recombinant plasmids. The recombinant plasmids were transferred into the corresponding mutant by triparental conjugation. The transconjugants carrying the recombinant plasmid were screened on NYG agar plates with rifampicin, kanamycin and tetracycline. The resulting strains were named, respectively, C3813nk, C3814nk and C3815nk (Table 1).

Extracellular polysaccharide assay. To estimate EPS production, strains were cultured in $100 \mathrm{ml}$ NYG liquid medium containing $2 \%$ (w/v) glucose at $28^{\circ} \mathrm{C}$ with shaking at 200 r.p.m. for 3 days. EPS was precipitated from the culture supernatant with ethanol, dried, and weighed as described by Tang et al. (1991). EPS structure analysis

Table 2. Primers

The underlined sequences indicate the restriction sites for BamHI and HindIII.

\begin{tabular}{|c|c|c|}
\hline Primer & Nucleotide sequence $\left(5^{\prime} \rightarrow 3^{\prime}\right)$ & Amplified segment or primer location \\
\hline $3811 \mathrm{~F}$ & ACAGTTGGATCCTGCAGGCCTGGCAATACT & 246 bp DNA fragment, spans nucleotides 119 to 364 \\
\hline $3811 \mathrm{R}$ & ACAGTTAAGCTT TATGCACCACCAGCGTGG & of the XC3811 ORF sequence \\
\hline C3811R & ATCAATCGCGCTCACAGG & Located downstream of XC3811 \\
\hline $3812 \mathrm{~F}$ & ACAGTTGGATCCGGTGCTGTACCAGATGAT & 405 bp DNA fragment, spans nucleotides 591 to 995 \\
\hline $3812 \mathrm{R}$ & ACAGTTAAGCTTATCGGCGCCAGTTCCTTC & of the XC3812 ORF sequence \\
\hline C3812R & ATCACCAGCGGAGTTTGC & Located downstream of XC3812 \\
\hline $3813 \mathrm{~F}$ & ACAGTTAAGCTTCATGACCTCTTCAGGCTC & 369 bp DNA fragment, spans nucleotides 310 to 678 \\
\hline $3813 \mathrm{R}$ & ACAGTTGGATCCTTCGATCTGTATTGCACG & of the XC3813 ORF sequence \\
\hline C3813F & ACAGTTAAGCTTATGGACGCGTTGGTGATT & 1301 bp DNA fragment, spans from 226 bp upstream \\
\hline C3813R & ACAGTTGGATCCAAAATGCCTTCTGGCTAC & to $16 \mathrm{bp}$ downstream of the $\mathrm{XC} 3813$ ORF sequence \\
\hline $3814 \mathrm{~F}$ & ACAGTTGGATCCTAGCCAGAAGGCATTTTG & 390 bp DNA fragment, spans nucleotides 269 to 658 \\
\hline $3814 \mathrm{R}$ & ACAGTTAAGCTTTAGTCGTACTCGGCCATC & of the XC3814 ORF sequence \\
\hline $\mathrm{C} 3814 \mathrm{~F}$ & ACAGTTGGATCCTGAAGCCGTGAAACAGCT & 1096 bp DNA fragment, spans from $259 \mathrm{bp}$ upstream \\
\hline C3814R & ACAGTTAAGCTTATCGCCATTGGCTCAGTC & to $12 \mathrm{bp}$ downstream of the $\mathrm{XC} 3814$ ORF sequence \\
\hline $3815 \mathrm{~F}$ & ACAGTTAAGCTTAGACCAACACACCCAGGG & 357 bp DNA fragment, spans nucleotides 293 to 649 \\
\hline $3815 \mathrm{R}$ & ACAGTTGGATCCTACGCGATGTGGAAAACC & of the XC3815 ORF sequence \\
\hline C3815F & ACAGTTAAGCTTTATGTGCGCCAGAAGACC & 1478 bp DNA fragment, spans from 111 bp upstream \\
\hline C3815R & ACAGTTGGATCCTGATGCGGTCAATATGGT & to $77 \mathrm{bp}$ downstream of the XC3813 ORF sequence \\
\hline $3816 \mathrm{~F}$ & ACAGTTAAGCTTAAAGGCCACGGTCAACAG & 373 bp DNA fragment, spans nucleotides 678 to 1050 \\
\hline $3816 \mathrm{R}$ & ACAGTTGGATCCCTACCTCAACGACATCCT & of the XC3816 ORF sequence \\
\hline C3816 & TCACTCGGTGTCCAGGTT & Located downstream of XC3816 \\
\hline P18conF & GCCGATTCATTAATGCAGCTGGCAC & Located in $\mathrm{pK} 18 m o b$ \\
\hline
\end{tabular}




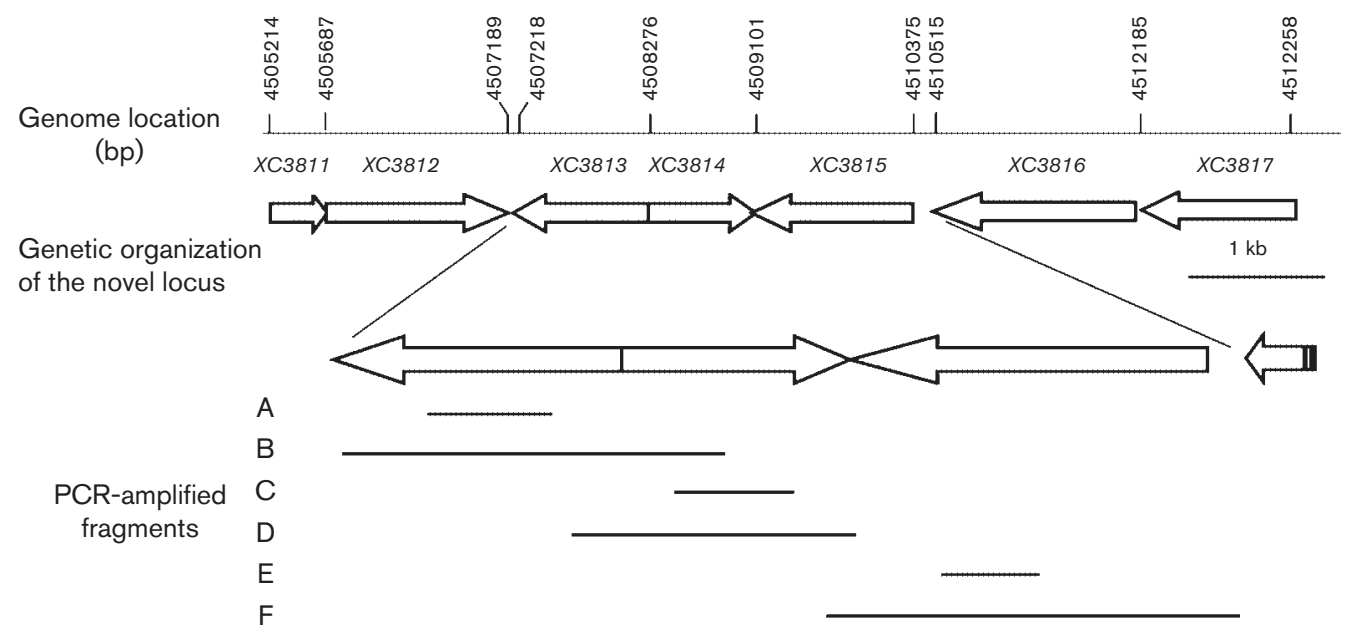

Fig. 1. Genetic and physical map of the novel gene cluster. The positions and orientations of the three genes are shown; arrows indicate the direction of transcription. The lower element shows the PCR fragments used for mutation and complementation analysis. A, $\mathrm{C}$ and $\mathrm{E}$ are internal fragments of $X \mathrm{C} 3813, X \mathrm{C} 3814$ and $X \mathrm{C} 3815$ respectively. These fragments

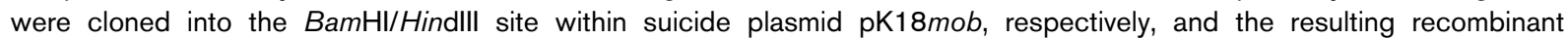
plasmids were used to mutagenize the corresponding ORF. B, D and F are DNA fragments that contained XC3813, XC3814 and $X$ C3815 respectively. These fragments were cloned into the BamHI/Hindlll site within pLAFR3 or pLAFR6 for complementation of the corresponding mutants.

was performed with Fourier transform infrared (FT-IR) spectra. FT-IR spectra were recorded on a Nicolet 5DX spectrometer. The dry sample powder was mixed with $\mathrm{KBr}$ and pressed into pellets under reduced pressure. The FT-IR spectra were obtained by scanning between 4000 and $450 \mathrm{~cm}^{-1}$.

Lipopolysaccharide analysis. LPS was prepared using an LPS extraction kit (iNtRON Biotechnology). LPS preparations were analysed using Tricine-SDS-PAGE (Lesse et al., 1990) and visualized by silver staining (Kittelberger \& Hilbink, 1993).

$\boldsymbol{\beta}$-Glucuronidase (GUS) activity assay. Xcc strains were cultured overnight and diluted to an $\mathrm{OD}_{600}$ of 0.5 , and $1.0 \mathrm{ml}$ of each was inoculated into $200 \mathrm{ml} \mathrm{NYG} \mathrm{medium} \mathrm{held} \mathrm{in} 500 \mathrm{ml}$ flasks. GUS activities were determined at $12 \mathrm{~h}$ intervals until $60 \mathrm{~h}$ by measurement of the $A_{415}$ using $p$-nitrophenyl $\beta$-D-glucuronide as the substrate, as described by Henderson et al. (1985).

Virulence assay. The virulence of $X c c$ to Chinese radish (Raphanus sativus) was tested by the leaf-clipping method (Dow et al., 2003). Seedlings with four fully expanded leaves were used for inoculation. Bacteria grown overnight in NYG liquid medium were washed and resuspended in water to an $\mathrm{OD}_{600}$ of 0.1 . Two or three fully expanded leaves per plant were cut with scissors dipped in the bacterial suspensions. Sixty leaves were inoculated in each independent experiment. Each treatment was repeated three times. Lesion length was measured 10 days after inoculation, and data were analysed by $t$-test.

The growth of bacteria in radish leaf tissue was measured by homogenizing a group of leaves (five leaves for each sample) in $9 \mathrm{ml}$ sterile water. Diluted homogenates were plated on NYG agar plates supplemented with rifampicin (for wild-type) or rifampicin plus kanamycin (for mutants). Bacterial c.f.u. were counted after incubation at $28^{\circ} \mathrm{C}$ for 3 days.

\section{RESULTS}

\section{Mutation analysis reveals three ORFs involved in EPS production}

Our preliminary work identified a number of EPS-deficient mutants by Tn 5 gus $A 5$ transposon insertional mutagenesis of the $X c c$ wild-type strain 8004 . One of the mutants, 151D09, was due to disruption of the ORF XC3814 (Table 1). In the reported genome sequence of strain 8004, the protein encoded by XC3814 (YP_244874) was assigned as a glycosyltransferase (Qian et al., 2005). The upstream ORFs XC3811, XC3812 and XC3813, and the downstream ORFs XC3815 and XC3816 are poorly characterized genes, and the proteins encoded by these ORFs (YP_244871, YP_244872, YP_244873, YP_244875, YP_244876) were annotated as 'conserved hypothetical proteins"' (Qian et al., 2005). These six ORFs are located in the genome sequence between position 4505214 and position 4512185 (Fig. 1).

To assess the function of these genes, mutants carrying insertional disruptions within the ORFs XC3811, XC3812, XC3813, XC3814, XC3815 and XC3816 were constructed and named 3811nk, 3812nk, 3813nk, 3814nk, 3815nk and $3816 n k$, respectively (Table 1 ; see Methods). To test the EPS production, these insertional mutants were grown on NYG agar plates supplemented with $2 \%$ glucose for 5 days. Mutants 3813nk, 3814nk and 3815nk displayed smaller colonies than the wild-type strain (Fig. 2a), while the other mutants formed normal wild-type colonies. The growth rates of the mutants did not differ from that of the wild-type in NYG liquid medium (Fig. 2b) or in MMX minimal 
(a)

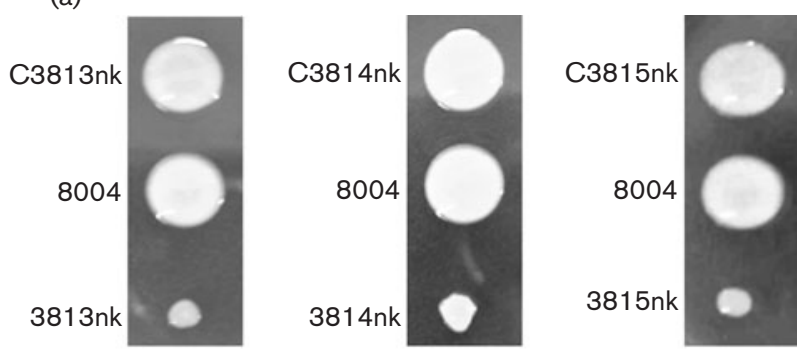

(b)

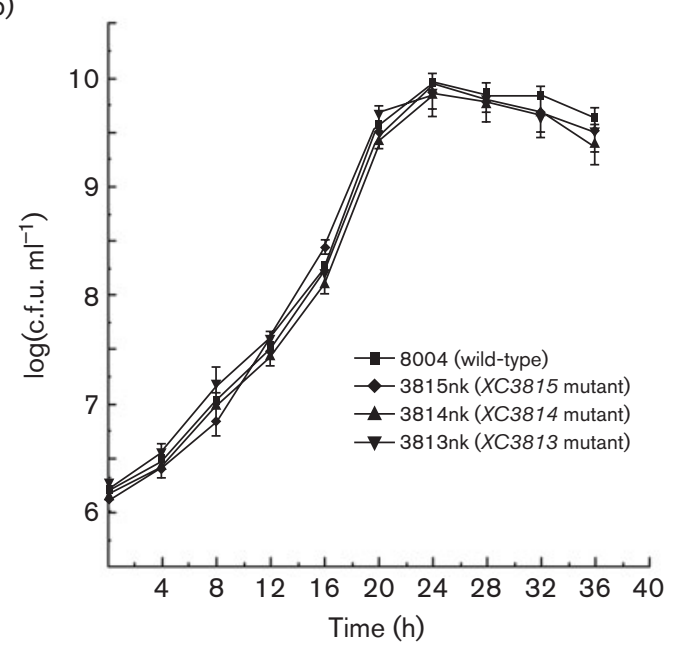

Fig. 2. Growth of $X_{c c}$ strains in glucose-containing medium. (a) Strains grown on NYG agar plates supplemented with $2 \%$ glucose for 5 days. Mutants of XC3813, XC3814 and XC3815 displayed smaller colonies than the wild-type strain 8004 , but the complemented strains formed colonies of normal size. (b) Growth curves of the mutants. Strains were inoculated into $100 \mathrm{ml} \mathrm{NYG} \mathrm{liquid} \mathrm{medium} \mathrm{containing} 2 \%$ glucose. Samples were taken in triplicate at intervals of $4 \mathrm{~h}$, diluted, and plated on NYG agar. Bacterial c.f.u. were counted after incubation at $28^{\circ} \mathrm{C}$ for 3 days. The mutants displayed normal growth rates.

medium (data not shown). These findings suggested that mutants 3813nk, 3814nk and 3815nk might produce less EPS than the wild-type. To quantitatively estimate the EPS production of the mutants, strains were grown in NYG liquid medium containing $2 \%$ glucose for 3 days and EPS was extracted from the cultures. The results showed that the mutants $3813 \mathrm{nk}, 3814 \mathrm{nk}$ and $3815 \mathrm{nk}$ produced significantly less EPS than the wild-type strain 8004 (Table 3). For complementation, plasmids pLATC3813, pLATC3814 and pLATC3815 (Table 1) were constructed by cloning a $1301 \mathrm{bp}$ fragment, a $1096 \mathrm{bp}$ fragment and a $1478 \mathrm{bp}$ fragment, each of which included the corresponding ORF (Fig. 1), into the vector pLAFR3. These plasmids were introduced into mutants $3813 \mathrm{nk}, 3814 \mathrm{nk}$ and $3815 \mathrm{nk}$ to form the complemented mutants C3813nk, C3814nk and C3815nk (Table 1; see Methods for details). The EPS yield of the complemented mutants showed no significant difference
Table 3. EPS production by $X_{c c}$ strains

Data are the mean $\pm S D$ of triplicate measurements; different letters in each data column indicate significant differences $(P=0.05 ; t$ test). Data presented are from a representative experiment and similar results were obtained in two other independent experiments.

\begin{tabular}{|lc|}
\hline Strain & EPS yield $\left(\mathbf{g ~ l}^{-\mathbf{1}}\right)$ \\
\hline 8004 (wild-type) & $9.75 \pm 0.25^{a}$ \\
3813nk (XC3813 mutant) & $4.03 \pm 0.35^{b}$ \\
C3813nk (complemented mutant) & $9.65 \pm 0.58^{a}$ \\
3814nk (XC3814 mutant) & $4.84 \pm 0.33^{b}$ \\
C3814nk (complemented mutant) & $9.53 \pm 0.60^{a}$ \\
3815nk (XC3815 mutant) & $3.12 \pm 0.23^{b}$ \\
C3815nk (complemented mutant) & $9.39 \pm 0.93^{a}$ \\
3811nk (XC3811 mutant) & $9.48 \pm 0.47^{a}$ \\
3812nk (XC3812 mutant) & $9.55 \pm 0.22^{a}$ \\
3816nk (XC3816 mutant) & $9.81 \pm 0.37^{a}$ \\
\hline
\end{tabular}

from that of the wild-type strain (Table 3, Fig. 2a), indicating that the mutations in XC3813, XC3814 and XC3815 could be complemented by the corresponding ORF in trans. The promoterless plasmid pLAFR6 harbouring the $1301 \mathrm{bp}$ fragment, the $1096 \mathrm{bp}$ fragment or the $1478 \mathrm{bp}$ fragment could also complement the corresponding mutant (data not shown), suggesting that XC3813, XC3814 and XC3815 have their own promoter.

The EPS of Xcc consists of pentasaccharide repeating units with the structure mannose- $1,4-\beta$-glucuronic acid-1,2- $\beta$ mannose-1,3- $\alpha$-cellobiose (Jansson et al., 1975). The assembly and polymerization of the repeated units have been attributed to the protein products of the gum genes (Ielpi et al., 1993). To estimate the effect of inactivation of XC3813, XC3814 or XC3815 on the EPS chemical structure, EPS from the mutant strains and the wild-type strain was analysed using FT-IR spectra. These spectra revealed that the EPS patterns of the mutants were similar to that of the wild-type (data not shown). The characteristic vibration peaks appeared in all the EPS samples and no obvious shift of these characteristic peaks was observed. This indicates that mutation in any of the three ORFs does not result in change in the pentasaccharide repeating units.

\section{Characterization of XC3813, XC3814 and XC3815}

Domain analysis with the SMART program (http://smart. embl-heidelberg.de/) showed that the 352 amino acid protein XC3813 contains a glycerophosphotransferase domain (PF04464, 4.7e-08) (residues 148-317). It has been reported that in Staphylococcus epidermidis, glycerophosphotransferase, encoded by the tagF gene, is responsible for polymerization of the main chain of teichoic acid (Fitzgerald \& Foster, 2000). The deduced XC3814 protein comprises 274 amino acids and contains a domain characteristic of glycosyltransferase family 2 (PF00535, 
2.80e-20) at its N-terminus (residues 14-177). Glycosyltransferase family 2 is a diverse family that transfers the sugar from UDP-glucose, UDP- $N$-acetylgalactosamine, GDP-mannose or CDP-abequose to a range of substrates including cellulose, dolichol phosphate and teichoic acids (Campbell et al., 1997). The deduced XC3815 protein, of 429 amino acids, harbours a Wzy conserved domain (PF04932, 1.7e-19), residues 270-341. The protein Wzy, an $\mathrm{O}$-antigen polymerase encoded by the gene $w z y$ (Reeves et al., 1996), is responsible for polymerization of the repeated O-antigen unit of LPS (Bengoechea et al., 2002). One of the features of the Wzy protein is that it has multiple putative membrane-spanning domains (Collins \& Hackett, 1991; De Kievit et al., 1995; Bengoechea et al., 2002). The deduced protein XC3815 is predicted to have 11 transmembrane segments, suggesting an integral membrane location.

These bioinformatic analyses suggested that XC3814 and XC3815 might affect LPS synthesis. To address this issue, LPS from the mutant and wild-type strains was prepared and analysed using SDS-PAGE. Under these conditions, the banding patterns of LPS from the mutant strains $3814 \mathrm{nk}$ and $3815 \mathrm{nk}$ were indistinguishable from the wild-type strain 8004 (data not shown). This result indicated that the XC3814 and XC3815 may not be involved in LPS synthesis.

To determine whether the inactivation of XC3813, XC3814 or $X C 3815$ reduces the expression level of the gum genes, the reporter plasmid pL6gumGUS, which carries the promoter region of the gum operon fused to the coding region for $g u s A$ (Vojnov et al., 2001), was transferred to the wild-type and mutant strains by triparental mating with the E. coli DH5 $\alpha$ donor strain and helper strain HB101/pRK2073. In the wildtype background the GusA level, determined enzymically, mirrors gum gene expression and is correlated closely with the level of EPS production (Vojnov et al., 2001). The transconjugant strains 8004/pL6gumGUS, 3813nk/ pL6gumGUS, 3814nk/pL6gumGUS and 3815nk/ pL6gumGUS (Table 1) were cultured in NYG liquid medium containing $2 \%(\mathrm{w} / \mathrm{v})$ glucose with shaking at 200 r.p.m. GUS activities were assayed as described by Henderson et al. (1985) at $12 \mathrm{~h}$ intervals. The results showed that the GUS activities in the mutant backgrounds were not significantly different $(P=0.05 ; t$-test $)$ from each other and from the wild-type background at each of the time points tested (Table 4). This indicates that inactivation of any of the ORFs XC3813, XC3814 or XC3815 has no effect on the transcription level of gum genes.

\section{$X C 3813, X C 3814$ and $X C 3815$ are required for full virulence}

The virulence assay for the $X c c$ strains was performed on Chinese radish by the leaf-clipping method (Dow et al., 2003). Xcc is a vascular pathogen and the leaf-clipping inoculation introduces the bacteria directly into the vascular system. Ten days after inoculation XC3813 and XC3815 mutant strains showed markedly reduced virulence compared with the wild-type strain: the mean lesion lengths caused by $3813 \mathrm{nk}$ and $3815 \mathrm{nk}$ were significantly shorter than that caused by the wild-type strain 8004 at $P=0.01$ (t-test). Furthermore the mutant strain $3814 \mathrm{nk}$ almost completely lost virulence and hardly induced any symptoms on the inoculated leaves (Fig. 3a,b). In contrast, lesion lengths caused by the complemented strains and the wildtype strain were not significantly different at $P=0.05$ (Fig. 3b), indicating that the virulence of the mutants $3813 \mathrm{nk}, 3814 \mathrm{nk}$ and $3815 \mathrm{nk}$ could be fully restored by the recombinant plasmids pLATC3813, pLATC3814 and pLATC3815, respectively.

To determine the role of XC3813, XC3814 and XC3815 in growth of $X c c$ in the host, numbers of bacterial cells of the corresponding mutants in infected radish leaves were calculated. For mutants $3813 \mathrm{nk}$ and $3815 \mathrm{nk}$, the number of bacterial cells recovered from the infected leaves was approximately 10 -fold lower than that of the wild-type strain 5 days post-inoculation and onward (Fig. 3c). For mutant $3814 \mathrm{nk}$, the number of bacterial cells was approximately 100-fold lower than that of the wild-type strain 5 days post-inoculation and onward (Fig. 3c). The growth of 3813nk, 3814nk and 3815nk in planta could be completely restored by pLATC3813, pLATC3814 and pLATC3815, respectively. These results reveal that XC3813, XC3814 and $X C 3815$ affect growth of $X c c$ as well as symptom production in planta.

Table 4. GUS activities of $X_{C c}$ strains

Strains were grown in NYG liquid medium with $2 \%(\mathrm{w} / \mathrm{v})$ glucose. $\beta$-Glucuronidase (GUS) activities were measured at $12 \mathrm{~h}$ intervals; values are the mean \pm SD of triplicate measurements. Data presented are from a representative experiment and similar results were obtained in two other independent experiments.

\begin{tabular}{|c|c|c|c|c|c|}
\hline \multirow[t]{2}{*}{ Strain } & \multicolumn{5}{|c|}{ GUS activity ( $\mathrm{mg} p$-nitrophenol product $\min ^{-1}$ per $\mathrm{OD}_{600}$ unit) } \\
\hline & $12 \mathrm{~h}$ & $24 \mathrm{~h}$ & $36 \mathrm{~h}$ & $48 \mathrm{~h}$ & $60 \mathrm{~h}$ \\
\hline 8004/pL6gumGUS & $0.502 \pm 0.089$ & $0.835 \pm 0.066$ & $1.491 \pm 0.072$ & $1.852 \pm 0.095$ & $2.182 \pm 0.062$ \\
\hline 3813nk/pL6gumGUS & $0.452 \pm 0.085$ & $0.829 \pm 0.079$ & $1.537 \pm 0.043$ & $1.830 \pm 0.076$ & $2.232 \pm 0.059$ \\
\hline 3814nk/pL6gumGUS & $0.560 \pm 0.055$ & $0.933 \pm 0.075$ & $1.423 \pm 0.047$ & $1.923 \pm 0.096$ & $2.250 \pm 0.063$ \\
\hline 3815nk/pL6gumGUS & $0.553 \pm 0.059$ & $0.909 \pm 0.124$ & $1.631 \pm 0.088$ & $1.900 \pm 0.099$ & $2.191 \pm 0.142$ \\
\hline
\end{tabular}


(a)
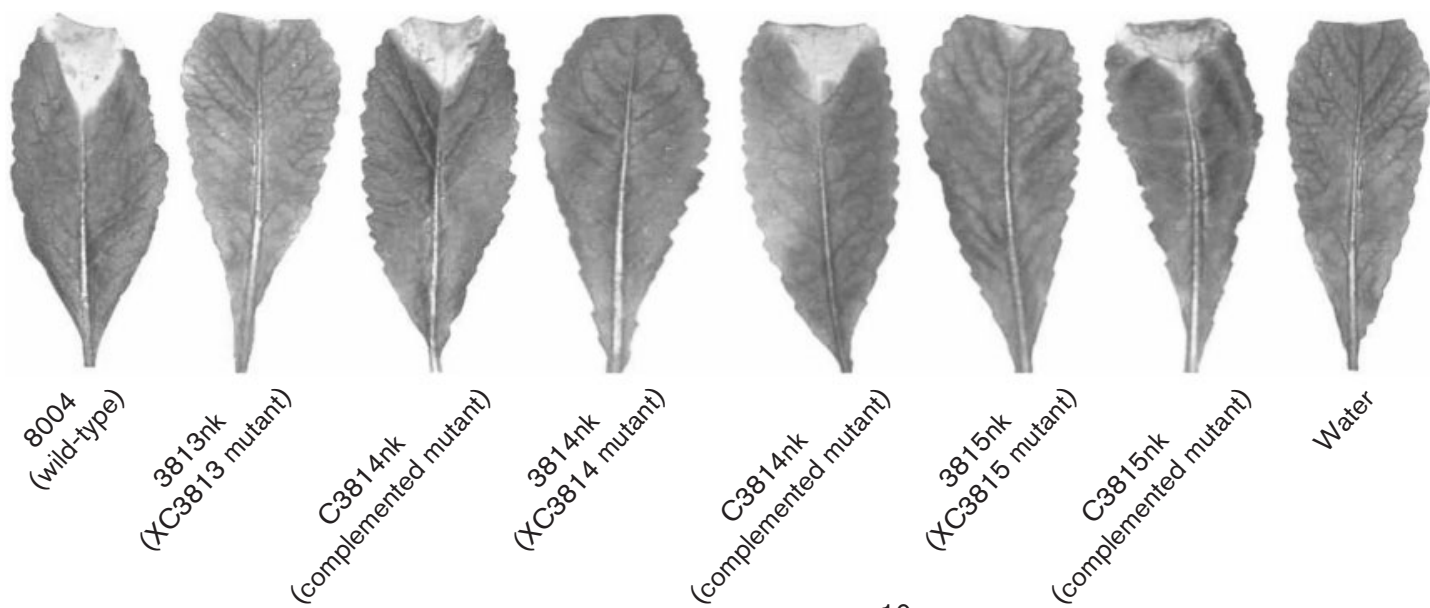

$3^{2}$

(b)

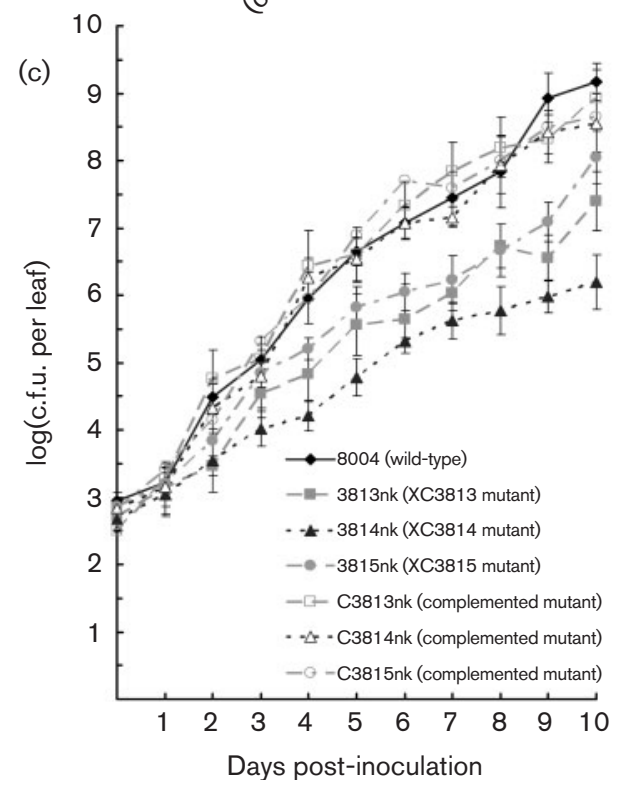

Fig. 3. XC3813, XC3814 and XC3815 are required for full virulence of $X_{C C}$ to Chinese radish. (a) Symptom production on leaves 10 days after inoculation by clipping with strains and water (mock inoculation). (b) Mean lesion lengths caused by mutants and the wild-type strain. 3814nk has almost completely lost virulence; 3813nk and 3815nk have markedly lost virulence; as analysed by $t$-test, the mean lesion lengths caused by $3813 \mathrm{nk}$ and $3815 \mathrm{nk}$ were significantly shorter $(P=0.01)$ than those caused by the wild-type. Values are the mean \pm SD from 15 measurements. (c) Bacterial populations of strains in host plant leaves. Inoculated leaves for each strain were taken daily and homogenized in sterile water. The homogenates were diluted and then plated on agar plates. Bacterial c.f.u. were counted after incubation for 3 days. Data are the mean \pm SD from three repeats.

\section{DISCUSSION}

In this work, we have described a novel cluster, comprising three ORFs, XC3813, XC3814 and XC3815, involved in the production of EPS and virulence of Xcc. An SSDB Gene Cluster Search (http://www.genome.jp) revealed that homologues of XC3813, XC3814 and XC3815 in the same gene order occur in the genomes of related phytopathogenic bacteria: XOO0589-0591 in Xanthomonas oryzae KACC10331, XCV3920-3922 in Xanthomonas campestris pathovar vesicatoria, and XAC3795-3797 in Xanthomonas axonopodis pathovar citri. Homologous genes (XF19931995) also occur in Xylella fastidiosa 9a5c, although in this organism the orientation of the three genes differs from that of Xcc. The biochemical characteristics and physiological roles of these homologous proteins have not been reported.

The biosynthesis of EPS in Xcc occurs in at least two stages. Firstly, the repeating pentasaccharide unit is sequentially assembled while linked to a polyprenol through a diphosphate bridge. Secondly, the repeating units are polymerized and the polymer is exported from the cell. This second stage 
is still poorly understood. The protein products of the gum gene cluster direct assembly of pentasaccharide repeating units, polymerization and the export of EPS (Vanderslice et al., 1990; Ielpi et al., 1993). Mutations in certain gum genes that affect EPS structure also reduce the level of EPS production (Katzen et al., 1998). In this work, we have shown that mutation of XC3813, XC3814 or XC3815 causes reduced EPS production but neither the structure of the pentasaccharide repeating unit nor the transcription of the gum genes is altered. How then do XC3813, XC3814 and XC3815 influence EPS production?

Bioinformatic analysis suggested that XC3814 and XC3815 have a role in LPS synthesis. XC3814 is annotated as encoding an LPS core biosynthesis glycosyltransferase by reason of the shared limited similarity with the protein $\mathrm{KdtX}$ (39\% identity and $54 \%$ similarity) from Serratia marcescens (accession no. Q54435; Guasch et al., 1996), the WaaE protein (39\% identity and $51 \%$ similarity) from Klebsiella pneumoniae (accession no. Q9XC90; Regue et al., 2001), and the LpsC protein (33\% identity and $48 \%$ similarity) from Sinorhizobium meliloti (accession no. Q9R9M9; Lagares et al., 2001). KdtX, WaaE and LpsC have been predicted to be LPS core biosynthesis glycosyltransferases. Consistent with this assertion, mutation of $k d t X, w a a E$ and $l p s C$ led to changes in LPS pattern on SDS-polyacrylamide gels such that the core LPS from the mutant strains migrated faster than that of the wild-type strain (Guasch et al., 1996; Regue et al., 2001; Lagares et al., 2001). XC3815 was predicted bioinformatically to be a cytoplasmic membrane protein containing the Wzy domain. Wzy has been shown to be responsible for polymerization of the repeated $\mathrm{O}$-antigen unit of LPS in some bacteria, where inactivation of the $w z y$ gene led to the loss of the O-antigen ladder in the LPS electrophoresis pattern (Collins \& Hackett, 1991; Bengoechea et al., 2002; Grozdanov et al., 2002; Tao et al., 2004). In this work, inactivation of XC3814 or XC3815 did not alter the LPS pattern, suggesting that XC3814 and XC3815 are not involved in LPS synthesis. Bioinformatic analysis suggested that XC3813 has a glycerol-phosphate transfer domain. However, structural analyses of LPS have not indicated the presence of glycerol-phosphate residues (Corsaro et al., 2001; Raetz \& Whitfield, 2002; Molinaro et al., 2003), and our analysis of LPS failed to detect an effect of mutation of XC3813 on the electrophoretic mobility of LPS bands.

Although XC3813, 3814 and 3815 have no apparent role in LPS biosynthesis, it is possible that these proteins direct the synthesis of a different (as yet unidentified) surface polysaccharide, and that the loss of this polymer adversely affects EPS export or polymerization. A second possibility is that XC3813, 3814 and 3815 may act as accessory elements to Gum proteins involved in EPS export or polymerization. Further work is required to understand the molecular basis of the influence of this novel gene cluster on EPS production and this will be the subject of future investigations.

\section{ACKNOWLEDGEMENTS}

We are grateful to J. Maxwell Dow for kindly providing the reporter plasmid pL6gumGUS and critically reading the manuscript. This work was supported by the National Science Foundation of China (30470944 and 30130010) and the '863' Program of the Ministry of Science and Technology of China (2004AA223060).

\section{REFERENCES}

Alvarez, A. M. (2000). Black rot of crucifers. In Mechanisms of Resistance to Plant Diseases, pp. 21-52. Edited by A. J. Slusarenko and others. Dordrecht: Kluwer.

Bengoechea, J. A., Pinta, E., Salminen, T., Oertelt, C., Holst, O., Radziejewska-Lebrecht, J., Piotrowska-Seget, Z., Venho, R. \& Skurnik, M. (2002). Functional characterization of Gne (UDP- $N$ acetylglucosamine-4-epimerase), Wzz (chain length determinant), and Wzy (O-antigen polymerase) of Yersinia enterocolitica serotype O:8. J Bacteriol 184, 4277-4287.

Boyer, H. W. \& Roulland-Dussoix, D. (1969). A complementation analysis of the restriction and modification of DNA in Escherichia coli. J Mol Biol 41, 459-472.

Campbell, J. A., Davies, G. J., Bulone, V. \& Henrissat, B. (1997). A classification of nucleotide-diphospho-sugar glycosyltransferases based on amino acid sequence similarities. Biochem J 326, 929-939.

Capage, M. A., Doherty, D. H., Betlach, M. R. \& Vanderslice, R. W. (1987). Recombinant-DNA mediated production of xanthan gum. International patent WO87/05938.

Collins, L. V. \& Hackett, J. (1991). Molecular cloning, characterization, and nucleotide sequence of the $r f c$ gene, which encodes an O-antigen polymerase of Salmonella typhimurium. J Bacteriol 173, 2521-2529.

Corsaro, M. M., De Castro, C., Molinaro, A. \& Parrilli, M. (2001). Structure of lipopolysaccharides from phytopathogenic bacteria. In Recent Research Developments in Phytochemistry, pp. 119-138. Edited by G. Pandalai. Trivandrum: Research Signpost.

Daniels, M. J., Barber, C. E., Turner, P. C., Cleary, W. G. \& Sawczyc, M. K. (1984a). Isolation of mutants of Xanthomonas campestris pathovar campestris showing altered pathogenicity. J Gen Microbiol 130, 2447-2455.

Daniels, M. J., Barber, C. E., Turner, P. C., Sawczyc, M. K., Byrde, R. J. \& Fielding, A. H. (1984b). Cloning of genes involved in pathogenicity of Xanthomonas campestris pv. campestris using the broad host range cosmid pLAFR1. EMBO J 3, 3323-3328.

da Silva, A. C., Ferro, J. A., Reinach, F. C., Farah, C. S., Furlan, L. R., Quaggio, R. B., Monteiro-Vitorello, C. B., Van Sluys, M. A., Almeida, N. F. \& other authors (2002). Comparison of the genomes of two Xanthomonas pathogens with differing host specificities. Nature 417, 459-463.

De Crècy-Lagard, V., Glaser, P., Lejeune, P., Sismeiro, O., Barber, C. E., Daniels, M. J. \& Danchin, A. (1990). A Xanthomonas campestris pv. campestris protein similar to catabolite activation factor is involved in regulation of phytopathogenicity. J Bacteriol 172 , $5877-5883$

De Kievit, T. R., Dasgupta, T., Schweizer, H. \& Lam, J. S. (1995). Molecular cloning and characterization of the $r f c$ gene of Pseudomonas aeruginosa (serotype 05). Mol Microbiol 16, 565-574.

Dow, J. M. \& Daniels, M. J. (1994). Pathogenicity determinants and global regulation of pathogenicity in Xanthomonas campestris pv. campestris. In Molecular and Cellular Mechanisms in Bacterial Pathogenesis of Plants and Animals, pp. 29-41. Edited by J. L. Dangl. Berlin: Springer. 
Dow, J. M., Crossman, L., Findlay, K., He, Y.-Q., Feng, J.-X. \& Tang, J.-L. (2003). Biofilm dispersal in Xanthomonas campestris is controlled by cell-cell signaling and is required for full virulence to plants. Proc Natl Acad Sci U S A 100, 10995-11000.

Fitzgerald, S. N. \& Foster, T. J. (2000). Molecular analysis of the $\operatorname{tag} F$ gene, encoding CDP-glycerol:poly(glycerophosphate) glycerophosphotransferase of Staphylococcus epidermidis ATCC 14990. J Bacteriol 182, 1046-1052.

Grozdanov, L., Zahringer, U., Blum-Oehler, G., Brade, L., Henne, A., Knirel, Y. A., Schombel, U., Schulze, J., Sonnenborn, U. \& other authors (2002). A single nucleotide exchange in the $w z y$ gene is responsible for the semirough O6 lipopolysaccharide phenotype and serum sensitivity of Escherichia coli strain Nissle 1917. J Bacteriol 184, 5912-5925.

Guasch, J. F., Pique, N., Climent, N., Ferrer, S., Merino, S., Rubires, X., Tomas, J. M. \& Regue, M. (1996). Cloning and characterization of two Serratia marcescens genes involved in core lipopolysaccharide biosynthesis. J Bacteriol 178, 5741-5747.

Henderson, R. F., Benson, J. M., Hahn, F. F., Hobbs, C. H., Jones, R. K., Mauderly, J. L., McClellan, R. O. \& Pickrell, J. A. (1985). New approaches for the evaluation of pulmonary toxicity: bronchoalveolar lavage fluid analysis. Fundam Appl Toxicol 5, 451-458.

Hotte, B., Rath-Arnold, I., Puhler, A. \& Simon, R. (1990). Cloning and analysis of a 35.3-kilobase DNA region involved in exopolysaccharide production by Xanthomonas campestris pv. campestris. J Bacteriol 172, 2804-2807.

Huynh, T. V., Dahlbeck, D. \& Staskawicz, B. J. (1989). Bacterial blight of soybean: regulation of a pathogen gene determining host cultivar specificity. Science 245, 1374-1377.

lelpi, L., Couso, R. O. \& Dankert, M. A. (1993). Sequential assembly and polymerization of the prenol-linked pentasaccharide repeating unit of the xanthan polysaccharide in Xanthomonas campestris. $J$ Bacteriol 175, 2490-2500.

Jansson, P. E., Keene, L. \& Lindberg, B. (1975). Structure of the extracellular polysaccharide from Xanthomonas campestris. Carbohydr Res 45, 275-282.

Katzen, F., Ferreiro, D. U., Oddo, C. G., lelmini, V., Becker, A., Pühler, A. \& lelpi, L. (1998). Xanthomonas campestris pv. campestris gum mutants: effects on xanthan biosynthesis and plant virulence. J Bacteriol 180, 1607-1617.

Kennedy, J. F. \& Bradshaw, I. J. (1984). Production, properties and applications of xanthan. Prog Ind Microbiol 19, 319-371.

Kittelberger, R. \& Hilbink, F. (1993). Sensitive silver-staining detection of bacterial lipopolysaccharides in polyacrylamide gels. J Biochem Biophys Methods 26, 81-86.

Köplin, R., Arnold, W., Hotte, B., Simon, R., Wang, G. \& Pühler, A. (1992). Genetics of xanthan production in Xanthomonas campestris: the $x a n A$ and $x a n B$ genes are involved in UDP-glucose and GDPmannose biosynthesis. J Bacteriol 174, 191-199.

Lagares, A., Hozbor, D. F., Niehaus, K., Otero, A. J., Lorenzen, J., Arnold, W. \& Pühler, A. (2001). Genetic characterization of a Sinorhizobium meliloti chromosomal region involved in lipopolysaccharide biosynthesis. J Bacteriol 183, 1248-1258.

Leong, S. A., Ditta, G. S. \& Helinski, D. R. (1982). Heme biosynthesis in Rhizobium. Identification of a cloned gene coding for deltaaminolevulinic acid synthetase from Rhizobium meliloti. J Biol Chem 257, 8724-8730.

Lesse, A. J., Campagnari, A. A., Bittner, W. E. \& Apicella, M. A. (1990). Increased resolution of lipopolysaccharides and lipooligosaccharides utilizing tricine-sodium dodecyl sulfate-polyacrylamide gel electrophoresis. J Immunol Methods 126, 109-117.

Miller, J. H. (1972). Experiments in Molecular Genetics. Cold Spring Harbor, NY: Cold Spring Harbor Laboratory.
Molinaro, A., Silipo, A., Lanzetta, R., Newman, M. A., Dow, J. M. \& Parrilli, M. (2003). Structural elucidation of the O-chain of the lipopolysaccharide from Xanthomonas campestris strain 8004. Carbohydr Res 338, 277-281.

Onsando, J. M. (1992). Black rot of crucifers. In Plant Diseases of International Importance. II: Diseases of Vegetable and Oil Seed Crops, pp. 243-252. Edited by H. S. Chaube, J. Kumar, A. N. Mukhopadhyay \& U. S. Singh. Englewood Cliffs, NJ: Prentice Hall. Poplawsky, A. R. \& Chun, W. (1998). Xanthomonas campestris pv. campestris requires a functional pigB for epiphytic survival and host infection. Mol Plant Microbe Interact 11, 466-475.

Qian, W., Jia, Y., Ren, S.-X., He, Y.-Q., Feng, J.-X., Lu, L.-F., Sun, Q., Ying, G., Tang, D.-J. \& other authors (2005). Comparative and functional genomic analyses of the pathogenicity of phytopathogen Xanthomonas campestris pv. campestris. Genome Res 15, 757-767.

Raetz, C. R. \& Whitfield, C. (2002). Lipopolysaccharide endotoxins. Annu Rev Biochem 71, 635-700.

Reeves, P. R., Hobbs, M., Valvano, M. A., Skurnik, M., Whitfield, C., Coplin, D., Kido, N., Klena, J., Maskell, D. \& other authors (1996). Bacterial polysaccharide synthesis and gene nomenclature. Trends Microbiol 4, 495-503.

Regue, M., Climent, N., Abitiu, N., Coderch, N., Merino, S., Izquierdo, L., Altarriba, M. \& Tomas, J. M. (2001). Genetic characterization of the Klebsiella pneumoniae waa gene cluster, involved in core lipopolysaccharide biosynthesis. J Bacteriol 183, 3564-3573.

Sambrook, J., Fritsch, E. F. \& Maniatis, T. (1989). Molecular Cloning: a Laboratory Manual, 2nd edn. Cold Spring Harbor, NY: Cold Spring Harbor Laboratory.

Schafer, A., Tauch, A., Jager, W., Kalinowski, J., Thierbach, G. \& Puhler, A. (1994). Small mobilizable multi-purpose cloning vectors derived from the Escherichia coli plasmids pK18 and pK19: selection of defined deletions in the chromosome of Corynebacterium glutamicum. Gene 145, 69-73.

Staskawicz, B., Dahlbeck, D., Keen, N. \& Napoli, C. (1987). Molecular characterization of cloned avirulence genes from race 0 and race 1 of Pseudomonas syringae pv. glycinea. J Bacteriol 169, 5789-5794.

Tang, J.-L., Gough, C. L. \& Daniels, M. J. (1990). Cloning of genes involved in negative regulation of production of extracellular enzymes and polysaccharide of Xanthomonas campestris pathovar campestris. Mol Gen Genet 222, 157-160.

Tang, J.-L., Liu, Y.-N., Barber, C. E., Dow, J. M., Wootton, J. C. \& Daniels, M. J. (1991). Genetic and molecular analysis of a cluster of $r p f$ genes involved in positive regulation of synthesis of extracellular enzymes and polysaccharide in Xanthomonas campestris pathovar campestris. Mol Gen Genet 226, 409-417.

Tao, J., Feng, L., Guo, H., Li, Y. \& Wang, L. (2004). The O-antigen gene cluster of Shigella boydii $\mathrm{O} 11$ and functional identification of its wzy gene. FEMS Microbiol Lett 234, 125-132.

Turner, P., Barber, C. \& Daniels, M. J. (1984). Behavior of the transposons Tn5 and Tn7 in Xanthomonas campestris pv. campestris. Mol Gen Genet 195, 101-107.

Vanderslice, R. W., Doherty, D. H., Capage, M. A., Betlach, M. R., Hassler, R. A., Henderson, N. M., Ryan-Graniero, J. \& Tecklenburg, M. (1990). Genetic engineering of polysaccharide structure in Xanthomonas campestris. In Biomedical and Biotechnological Advances in Industrial Polysaccharides, pp. 145-156. Edited by V. Crescenzi, I. C. M. Dea, S. Paoletti, S. S. Stivala \& I. W. Sutherland. New York: Gordon \& Breach.

Vojnov, A. A., Slater, H., Daniels, M. J. \& Dow, J. M. (2001). Expression of the gum operon directing xanthan biosynthesis in Xanthomonas campestris and its regulation in planta. Mol Plant Microbe Interact 14, 768-774. 
Windgassen, M., Urban, A. \& Jaeger, K. E. (2000). Rapid gene inactivation in Pseudomonas aeruginosa. FEMS Microbiol Lett 193, 201-205.

Yanisch-Perron, C., Vieira, J. \& Messing, J. (1985). Improved M13 phage cloning vectors and host strains: nucleotide sequences of the M13mp18 and pUC19 vectors. Gene 33, 103-119.
Yun, M. H., Torres, P. S., El Oirdi, M., Rigano, L. A., Gonzalez-Lamothe, R., Marano, M. R., Castagnaro, A. P., Dankert, M. A., Bouarab, K. \& Vojnov, A. A. (2006). Xanthan induces plant susceptibility by suppressing callose deposition. Plant Physiol 141, 178-187.

Edited by: M. S. Ullrich 